\title{
BIODESIGN AND ENTREPRENEURSHIP
}

\author{
(BIYODIZAYN VE GIRISSIMCILIK)
}

\author{
Sultan GÜLÇE İZ ${ }^{1}$, Fazilet VARDAR SUKAN ${ }^{2}$
}

\begin{abstract}
$7^{\text {th }}$ Bioengineering Congress with a theme of 'Biodesign; Solutions of Nature for Societal Challenges' was organized by Ege University, Department of Bioengineering at Izmir Architecture Hall between $19^{\text {th }}-21^{\text {st }}$ November, 2015, as a closing panel 'Biodesign \& Entrepreneurship' was organized with leading participants on the topic. In this panel the questions to be addressed were expected to answer; 'What can be done to catalyse the development of innovative bioengineering approaches to the solutions of important problems in biomedical research, clinical investigations, and medical practice at global and national level?'. This review summarizes the approach of experts to the selected questions to shed light on the future routes of 'Biodesign and Entrepreneurship' pathway for Turkey.
\end{abstract}

Keywords: Bioengineering, Biodesign, Entrepreneurship, Design driven innovation, Commercialization

\section{$\ddot{O} Z$}

7. Biyomühendislik Kongresi, 'Biyodizayn; Doğanın Toplumsal Sorunlara Çözümleri' teması ile, 1921 Kasım, 2015 tarihinde, İzmir Mimarlık Merkezi’nde düzenlenmiştir. Kongrenin kapanışında lider uzmanlardan oluşan bir katılımcı profili ile 'Biyodizayn ve Girişimcilik' konulu bir panel düzenlenmiştir. Biyodizayn ve Girişimcilik temalı bu panelde, sorulan soruların, 'Biyomedikal araştırma, klinik araştırma ve medikal pratikte önemli sorunlara global ve ulusal düzlemde, inovatif biyomühendislik yaklaşımlarının nasıl gelişstirilebileceği' sorularına cevap aranmıştır. Genel olarak, Türkiye'de biyo-girişimcilik, biyostart-uplara dizayn yaklaşıml inovasyon, biyo-girişimciliğinin geliştirilmesi, kültür alışkanlıkları ve girişimcilik, biyomühendislik araştırmalarının ticarileştirme modelleri, translasyonel tıp ve Türkiye'de biyo-girișimcilik nasil cesaretlendirilebilinir sorularına cevap aranmıștır. Bu derlemede, seçilen sorulara verilen cevaplar, 'Biyodizayn ve Girişimcilik' yolunda yapılacaklara ışık tutması açısından özetlenmiştir.

Anahtar Kelimeler: Biyomühendislik, Biyodizayn, Girişimcilik, Dizayn temelli inovasyon, Ticarileştirme

\footnotetext{
1 Ege University, Faculty of Engineering, Department of Bioengineering, 35100 Bornova/Izmir/Türkiye, sultan.gulce.iz@ege.edu.tr (Corresponding Author)

2 Ege University, Faculty of Engineering, Department of Bioengineering, 35100 Bornova/Izmir/Türkiye, fazilet.vardar.sukan@ege.edu.tr
} 


\section{INTRODUCTION}

Many major biotechnological research problems are best addressed with a multidisciplinary approach that bridges life sciences and physical sciences. Bioengineering integrates principles from diverse technical and biomedical fields, and the resulting multidisciplinary research provides new understanding, novel products, and innovative technologies that improve basic knowledge, human health, and quality of life. Biodesign is a tool of bioengineering for unlocking the interdisciplinary barriers and translating rules of nature for solving complex societal challenges. The major solutions could be translated as high value added products when biodesign intersects with entrepreneurship which is described generally as the capacity and willingness to develop, organize and manage a business venture to create a societal added-value, along with any of its risks in order to make a profit. It entails recognizing the right opportunity, finding resources to pursue the opportunity and creating the right team to do so.

$7^{\text {th }}$ Bioengineering Congress with a theme of 'Biodesign; Solutions of Nature for Societal Challenges' was organized by Ege University, Department of Bioengineering at Izmir Architecture Hall between $19^{\text {th }}-21^{\text {st }}$ November, 2015.

The Congress host a total of 144 participants from different universities with 28 oral and 67 poster presentations. Two workshops entitled; "Emergence of Engineered Models in Personalized Medicine" and 'Biodesign at the Intersection of Bioengineering and Creativity' were organized parallel to the congress. In addition two bioart exhibitions, one bioart contest and a closing panel entitled 'Biodesign \& Entrepreneurship' were held. The panel participants listed below have different backgrounds with a wide range of different views on the topic; Fazilet Vardar Sukan, Prof. Dr. Ege University, Head of Department of Bioengineering, and Director of Ege University, Science and Technology Center-Technology Transfer Office (EBILTEM-TTO) moderated the panel and shared her experiences as a bioengineer on bioprocess development of novel bioproducts, in addition as an expert on university-industry collaboration and entrepreneurship.

Antonios Mikos, Prof., Dr., Bioengineering and Chemical and Biomolecular Engineering, Rice University, shared his academic experience related mainly in translational medicine and entrepreneurship education.

Bahattin Koç, Prof. Dr., Faculty of Engineering and Natural Sciences, Sabanci University shared his multidisciplinary experience as being an industrial engineer and working on manufacturing and 3D realization mainly on tissue engineering approaches.

Cüneyt Tuğrul; Op. Med.,Breast Cancer Treatment Clinic, Izmir, shared his experience with a clinician point of view.

Melissa Sterry, Design Scientist, School of Architecture \& Landscape, The University of Greenwich, shared her experience on UK entrepreneurship situation.

Serdar Alpan, Prof. Dr., Pharmacology, Biotechnology Group Leader, Turgut Ilac, shared his experience on their big biopharmaceutical investment in Turkey in collaboration with Merck-Milipore. 
This report summarizes the topics which were discussed in the closing panel entitled 'Biodesign \& Entrepreneurship' in light of the authors' experiences trough the panel participants' point of views.

\section{A REVIEW OF TOPICS DISCUSSED}

In this panel six different topics; bio-entrepreneurship in Turkey, design driven innovation implementation to biostart-ups, fostering bio-entrepreneurship, culture attitudes and entrepreneurship, models to commercialize bioengineering research, translational medicine and ways to encourage bio-entrepreneurship in Turkey were discussed.

\subsection{Bio-Entrepreneurship in Turkey and Europe}

The landscape of Turkey must be understood by bio-entrepreneurs and design must be done trough their needs, the entrepreneurs should be focused on the solutions of specific problems. For example, Turkey has a huge therapeutic drugs market and several pharmaceutical investments were made in this sector. However, the technology level in Turkey is far from to reach a satisfying end-product that's why international technology transfer agreements are done with a big pharmaceutical company to set the high technology factory in Turkey. Sufficient financing, technology, man power and time must be taken into consideration to have the investments long living and competitive.

Biotechnology sector has a high failure rate however the high risk areas are the important ones. Africa, India and South Asia must be taken into consideration as new emerging markets. In addition, every initiative does not need high implementation costs, low cost investments are also very important.

\subsection{Design Driven Innovation Implementation to Biostartups}

Design driven innovation gains importance in Bioengineering approaches because solutions must be innovative enough to solve the high challenging bioengineering problems. Design driven innovation and bioengineering as a discipline have commons in their descriptions; design driven strategy has a multi-focusing approach consisting of strategy formulation by listening; ideation strategy by interpretation, strategy implementation by broadcasting like the multidisciplinary bioengineering approaches [1].

Start ups in Bioengineering usually have a revolutionary idea however design driven innovation approaches should be used; to develop innovative business models that are scalable and profitable as well as to develop innovative marketing strategies. A startup should not be focused on the product only; market, competitors, users, suppliers to be identified real opportunities for innovation [2].

In addition, entrepreneurship is important and it should be thought in undergraduate, graduate, and business classes. Furthermore, commercialization courses are also needed in which interdisciplinary and multidisciplinary teams were made to design something to solve a specific problem and if possible translate into start ups in the universities or even in high schools.

\subsection{How Can We Foster Bio-Entrepreneurship in Turkey?}

Many people have innovative ideas in Turkey however the system does not fully support the innovators, thus, it must be redesigned to overcome the bureaucracy, the major obstacle. 
Most of the mature figures; like Bill Gates, made the difference so there must be a genetic background and a niche like Silicon Valley in USA to encourage entrepreneurship.

Medical and pharmaceutical areas are risky business and entrepreneurs must be supported, in this manner the risk financing gains importance. However, Turkey's global innovation data shows that opportunity to start ups, competition and risk acceptance are very low.

\subsection{Does Culture Attitude Affects Entrepreneurship?}

A belief must be created for the innovative product, like a future vision with quality criteria. Especially in orthopedics, there is a common sense that the quality standards are not high enough although they bear the signs of CE (Conformity of Europe) and TSE (Turkish Standards Institution).

5 to 10 years ahead must be taken into consideration with a global thinking, FDA (Food and Drug Administration) and EMA (European Medicines Agency) regulations must be followed and local market should not be on the center of attendance, the industry is interested in the best product not if it is the national or international product; quality, global market and highest technology must be very well studied in entrepreneurship designs.

\subsection{What Models Can be Used to Commercialize Bioengineering Research?}

In a specialized area like medical devices and tissue engineering, the products work very well but the implementation and large scale production costs are very high, thus cost reduction must always be taken into consideration. It's mostly much more challenging to lower down the cost for developing countries than for developed countries [3].

The commercialization policy in UK was given as an example. There was a competition announced (Longitude Prize*) and public was asked to choose the biggest problem to solve; they've chosen antibiotic resistance. After that, a global competition launched, what was looked for a simple diagnostic tool to detect antibiotic resistance. One of the biggest concern was scalability and second was cost. However, while looking for the cheapest, you have to have it regulated in terms of quality.

\subsection{What Can be Done to Full Fill the Gaps Between the Basic Research to be Translated into Industry?}

Strong collaborations between the academia and industry is needed. Funding bodies are needed to support the low TRL level projects for early-stage, high risk R\&D. In Turkey, TUBITAK (Turkish Scientific Research Council) has some funds related to master and doctorate students who are in industry to solve their related industrial problems with a jointly mentored approach. There are funds in Horizon 2020 to support the start up companies; fill gaps in funding for early-stage, high-risk research and innovation by SMEs as well as stimulating breakthrough innovations. There are also programs in EU like EATRIS-ERIC (European Infrastructure for Translational Medicine) to support translational medicine. Turkey is not in the program yet negotiations are still in progress. With a clinical perspective; antibiotics, medical patch, implants, stem cell research are very popular to be focused on to find the right niche for the bio- entrepreneurs.

\footnotetext{
* Longitude Prize is a challenge with a $£ 10$ million prize fund to help solve the problem of global antibiotic resistance. It is being run by NESTA (National Endowment for Science, Technology and the Arts) and supported by Innovate UK as funding partner.
} 


\section{FINAL REMARKS AND CONCLUSIONS}

Turkey has a huge market, and the market is open for new companies so entrepreneurs or national initiatives could find a niche otherwise international firms will do. To find the right business area, clinicians' problems must be taken into consideration and design through their needs is a good starting point to set up a novel business-see the opportunities, use the technologies - in fact it's important to do something more efficiently if something is being replicated nothing has been done. Vision, understanding, positive thinking, not giving up are important qualifications of entrepreneurs. However, getting education about entrepreneurship is a must, if the basics of commercialization have not been understood, a final product won't be made. IPR (intellectual property rights) must be protected by the universities or funding agencies to support enterpreneurs. Selecting your business partner is important, being in a good team brings financing - be a part of a good team and play in the golden league-Keep trying to become successful in business life, most of the initiatives failed more than once, people also learn from failure. And as a model system UK can be taken into consideration in which there are mentors behind the entrepreneurs, called catalyst who support the entrepreneurs in each step. Take home messages for the biodesigner entrepreneurs could be summarized in the following keywords; multidisciplinary teams, education, collaboration, crowd funding, questioning, finding the niche, quality; creating awareness in regulatory issues, knowing ourselves.

\section{ACKNOWLEDGEMENTS}

The authors would like to acknowledge the panel participants for attending and sharing their valuable experiences on the topic and Özge Andiç Çakır, Assoc. Prof, Ege University, EBILTEM-TTO for critically reviewing the manuscript.

\section{REFERENCES}

[1] Moroni I, Arruda A, Araujo K. The Design and Technological Innovation: How to Understand the Growth of Startups Companies in Competitive Business Environment, Procedia Manufacturing, Vol. 3, 2015, pp.2199-2204.

[2] Vianna M, Vianna I, Adler IK, Lucena B, Russo B. Design Thinking, Business Innovation, Rio de Jenerio, 2013.

[3] Bergmann J, Noble A, Thompson M. Why is Designing for Developing Countries More Challenging? Modelling the Product Design Domain for Medical Devices, Procedia Manufacturing, Vol. 3, 2015, pp.5693-5698.

\section{ÖZGEÇMIŞ/CV}

Sultan GÜLÇE İZ; Yrd. Doç. Dr. (Assist. Prof.)

She received her bachelor degree at Bioengineering Department, Ege University, Turkey and completed her master and doctorate at the same department. She conducted her post-doctoral research at University of California, Irvine, USA. She has been working as an assistant professor at Department of Bioengineering, Ege U. since September 2013. Her main research areas are DNA and recombinant protein vaccine development against infectious agents and as cancer immunotherapeutics, animal cell bioprocess, ELISA and rapid diagnostic kit development. She has attended the training programme of KOSGEB (Turkish Republic, Small and Medium Enterprise Development Organization) which was about Entrepreneurship, Business Development Process and Feasibility Report Preparation. She is a co-founder of an academic start-up located in Ege U., ideEGETGB technopark since January, 2015 which is specialized on diagnostics. 
yüksek lisans ve doktora derecelerini de aynı bölümden almıştır. Doktora sonrası eğitimini, Kaliforniya Universitesi, Irvine, ABD'de tamamlamıştır. Eylül 2013'den bu yana Ege Üniversitesi, Biyomühendislik Bölümü'nde yardımcı doçent olarak çalışmaktadır. Başlıca çalışma konuları enfeksiyöz ajanlara karşı ve kansere karşı DNA ve recombinant protein aşısı geliştirilmesi, hayvan hücre biyoprosesi, ELISA ve hızlı tanı testleri geliştirilmesidir. KOSGEB (T.C. Küçük ve Orta Ölçekli Işletmeleri Geliştirme ve Destekleme Idaresi Başkanlığl) tarafindan düzenlenen Girişimcilik, İş geliştirme Prosesi ve Fizibilite raporu hazırlanması eğitimlerine katılmıştır. Ocak 2015'den beri Ege Ü., Teknopark bölgesinde (ideEGETGB) yer alan ve tanı kiti geliştirmek üzere uzmanlaşan akademik bir şirketin kurucu ortaklarındandır.

Fazilet VARDAR SUKAN; Prof. Dr. (Prof.)

She graduated Ege University, Faculty of Engineering, Department of Chemical Engineering, she had taken her doctorate degree in Biochemical Engineering at University College London, UK at 1981. She started working as an assistant professor at Ege U., Chemical Engineering Department at 1982, became an associate professor at 1985 and became professor at 1992 at the same department. She has been working as head of the bioengineering department since 2000. She has more than 100 scientific articles, 2 books, several book chapters, many scientific presentations. She has research experiences in $5^{\text {th }}, 6^{\text {th }}, 7^{\text {th }}$ European framework programmes with a total of fifteen projects. In addition to her scientific activities, she has been heading Ege U., Science and Technology Center since 1998, which officially supported by Turkish Research Council (TUBITAK) as the technology transfer office of Ege U. in 2013 (EBILTEM-TTO). VARDAR SUKAN is representing Ege U. in different platforms and organizations as means of university-industry relations, technology transfer, intellectual and industrial property rights, entrepreneurship, national-international projects and innovation policies.

Prof. Dr. VARDAR SUKAN, 1978 yllında Ege Üniversitesi Mühendislik Fakültesi Kimya Mühendisliği Bölümü'nden mezun olduktan sonra doktorasını Ingiltere University College London'da Biyokimya Mühendisliği alanında 1981 yılında tamamlamıştır. 1982 yılında Ege Ü. Kimya Mühendisliği Bölümü’nde yardımcı doçent olarak göreve başlamış 1985 'te doçent, 1992'de profesör olmuştur. 2000 yılında kuruluşunda öncülük ettiği 'Biyomühendislik Bölümü Başkanlığına' atanmıştır. 100 'ün üzerinde bilimsel yayını, 2 kitabl ve kitap bölümleri, çok sayıda bilimsel bildirisi mevcuttur. Bugüne kadar biri Avrupa Birliği 5. çerçeve programında (ÇP), yedisi, 6. ÇP'da, sekizi 7. ÇP'nda olmak üzere toplam onbeş adet proje deneyimi bulunmaktadır. Bilimsel çalışmalarının yanı sıra 1998 yılından bu yana, Ege Ü. Bilim-Teknoloji Uygulama ve Araştırma Merkezi Müdürlügü’nü (EBILLTEM) ve 2013 yllından bu yana EBİLTEM-TTO (Teknoloji Transfer Ofisi) yöneticiliğini yapmaktadır. VARDAR SUKAN, farklı komite ve organizasyonlarda Ege Ü. 'sini, üniversitesanayi ilişkileri, teknoloji transferi, fikri ve sınai mülkiyet haklarl, girişimcilik, ulusal ve uluslararası destekli projeler ve inovasyon politikaları bağlamında temsil etmektedir. 